\title{
Ungdomsgrupper og samfunnsforhold
}

\author{
Av dosent NILS CHRISTIE.
}

I.

Noen ser på gjengen som roten til alt ondt. Om dens makt kunne brytes, ville hver enkelt deltaker bli forvandlet til en prektig hjemmekjær ungdom uten problemer hverken for seg selv eller for samfunnet. Andre ser på gjengen som en tilfeldig og betydningsl $\phi$ s mellomfase i ungdoms liv, mens atter andre ser på den som en n $\varnothing$ dvendighet om barn skal kunne f $\varnothing$ res over til voksent liv.

For å kunne vurdere forholdet er det viktig å fors $\phi$ ke å danne seg et bilde av gjengen $i$ et moderne industrisamfunn. Hvilke egenskaper er det som preger den? Har disse egenskapene sammenheng med forhold i samfunnet i sin alminnelighet? Kan det tenkes at gjengen eller ungdomsgruppene ${ }^{1}$ ) varetar enkelte samfunnsmessige behov?

For å belyse disse spørsmål vil det bli gjort et fors $\varnothing \mathrm{k}$ på å beskrive noen særtrekk ved ungdomsgrupperinger. Det vil bli slått ned på noen egenskaper som trolig er sosiologisk relevante, og det vil bli fors $\varnothing$ kt påvist hvorfor de er det. For å få fram det spesielle ved norske ungdomsgrupper vil disse bli sammenliknet med en siciliansk gjeng forfatteren kjenner litt til. I f $\varnothing$ rste halvdel av fremstillingen vil det være helt vanlige, ,normale“, norske ungdomsgrupper som beskrives. Mot slutten av artikkelen vil vi fors $\varnothing$ ke å få fram hvorledes mer kriminelle, eller i hvert fall kriminalitetstruede gjenger skiller seg fra de vanlige ungdomsgruppene.

Beskrivelsen av de vanlige norske grupperingene bygger ikke på annet enn hva de fleste norske byborgere har som bakgrunn: Litt deltakelse i ungdomsgrupperinger, litt observasjon og dernest et alminnelig inntrykk. Beskrivelsen av den sicilianske grupperingen bygger på et par måneders samvær med den, og må sees på med tilsvarende skepsis. Den sicilianske beskrivelsen har bare som formål å skape et bakteppe som kan gjøre norske forhold mer synlige.

Ingen av grupperingene beskrives med tanke på at de skal være representative. Det er hele tiden lagt an på å bygge opp fremstillingen omkring noen meget enkle og lett klassifiserbare kjennetegn. Fremstillingen tar sikte på å tjene som forarbeide for senere hypoteseprøving, og beskrivelsen er derfor i stor ut-

1) Betegnelsene ,gjeng“ og ,ungdomsgruppe“ vil bli benyttet om hverandre. "Gjeng" impliserer" ikke at aktivitetene på noen måte er kriminelle. 
strekning ,,idealtypisk“. Den passer ikke helt på noen enkelt ungdomsgruppe, men fremhever noen felles trekk ved mange. Når det gjelder beskrivelsen av de norske gruppene, håper jeg nok på å ha famlet meg fram mot egenskaper som i hvert fall er relevante for en del grupper i byer - kanskje særlig fra storbyenes middelklasser. Den sicilianske gruppen er ikke n $\varnothing$ dvendigvis representativ for noe annet enn seg selv: Den beskriver middelklasseungdom fra en liten solskinnsby.

\section{II.}

Forskjeller og likheter mellom de to samfunns ungdomsgrupper kan f $\varnothing$ rst settes opp i form av en del stikkord:

Norske ungdomsgrupper

To kjønn (kjønnsheterogene)

Lik alder (aldershomogene)

Ikke omgang mellom gjengmed-

lemmenes foreldre

Sterkt nabolagstilknyttet

Ikke foreldreinnflytelse

Oppløses 15-17 år

Reaksjonsdannelse
Sicilianske ungdomsgrupper

To kjønn (kjønnsheterogene)

Ulik alder (aldersheterogene)

Omgang mellom gjengmedlemmenes foreldre

Svakt nabolagstilknyttet

En viss foreldreinnflytelse

Fortsetter inntil ekteskap

Kontinuitetsfenomen

Den første egenskap i stikkordlisten går på medlemmenes kjønn. Her finnes også den eneste likhet. Både norske grupper og den sicilianske er kjønnsheterogene, de gir begge plass for gutter og piker. Det er imidlertid mye som tyder på at kvinnene svært ofte har lavere rang i systemene. De har mindre å si ved viktige avgjørelser, de blir av og til utelukket. Det gjelder spesielt i folkeskolealderen. Men i hvert fall blant middelklasseungdom er det nokså sjeldent å møte vanlige ungdomsgrupper som over et lengere tidsrom bare består av gutter eller bare består av piker. At begge kjønn er representert i ungdomsgruppen er imidlertid meget langt fra noen selvf $\varnothing$ lge. Sosialantropologer kan gi utallige eksempler på sterk kjønnsatskillelse i disse årene. Fra moderne industrisamfunn er det nok å se tilbake på Tyskland i mellomkrigstiden for å få eksempel på en samfunnsform hvor ungdomsgruppene i sterk grad var kjønnshomogene. Det kom etter manges oppfatning til å få politiske konsekvenser.

Bortsett fra denne likheten ved at begge gruppene har begge kjønn til stede, er det nesten bare ulikheter som møter oss i stikkordlisten. Først og fremst vil det være en betydelig forskjell mellom den norske ungdomsgruppen og den sicilianske ved at den norske har medlemmer med meget homogen alderssammensetning. Spesielt gjør dette seg gjeldende innen de spontant eta- 
blerte ungdomsgruppene. Det er her f $\phi$ rst og fremst jevnaldrende som s $\phi$ ker sammen. I ett og samme nabolag oppstår det gjerne nye grupper etter hvert som ungdomskullene vokser til - det er ikke slik at yngre blir tatt opp i allerede eksisterende grupperinger. I den sicilianske gruppen er dette helt annerledes. Der møter man en meget vid aldersfordeling. Man kan treffe en 40åring, noen 30-åringer, mange 20-åringer, noen ganske små barn. Dette har sammenheng med de neste ledd i stikkordrekken: Slektskapsrelasjonene og foreldreomgang.

Den sicilianske ungdomsgruppen vil i stor utstrekning bestå enten av slektninger eller av barn og unge hvis foreldre har en viss omgang med hverandre. Den norske gruppen vil her på ny være helt annerledes. Nettopp homogeniteten i alderssammensetningen gj $\phi r$ det vanskeligt å ha med s $\phi$ sken i gjengen. Andre slektninger vil dessuten som regel bo så spredt at eventuelle fettere og tremenninger heller ikke kommer i betraktning. Det samme gjelder barna til foreldrenes venner. Det normale mønster vil være at foreldrenes slekt og venner bor et annet sted enn $\mathbf{i}$ det nærmeste nabolag, mens ungdomsgruppene i den alt overveiende grad vil være nabolagsgrupper. I den sicilianske ungdomsgruppen er det derimot en tydelig tendens i retning av at medlemmenes foreldre enten har omgang med hverandre, eller er i slekt med hverandre. Det vide aldersspenn gjør det for det f $\phi$ rste mulig at $s \phi$ sken kan være medlem av den samme gjengen. Dessuten spiller slektskapstilknytningen i sin alminnelighet en langt større rolle. Vi skal snart komme tilbake til dette.

Men ved disse kontraster er det også fastlåst en ytterligere forskjell: Den sicilianske gjengen vil ha langt sterkere kommunikasjon over til foreldrene. Småsøsken som er med vil fungere som budbærere enten det nå er $\varnothing$ nsket eller uфnsket. De eldre medlemmene vil dessuten ha en fot i hver verden. Den ugifte onkel er en slags gjengleder, men samtidig bror av noen av medlemmenes far. Dette skaper muligheter for foreldreinnflytelse, men omvendt også muligheter for innflytelse fra ungdomsgruppen og over til foreldrene. Den norske ungdomsgruppen vil være i diametralt motsatt situasjon på dette punkt. Det som foregår i gjengen vil ofte være fullstendig ukjent for foreldrene. Det finnes ingen små eller store søsken som kan sladre eller informere. Det finnes ikke noen i foreldrenes vennekrets som har informasjon de kan bringe videre. De to systemene er meget effektivt atskilt.

Til gjengjeld vil vanlige norske foreldre kunne trekke et lettelsens sukk ved at disse ungdomsgjengene gjerne oppl $\varnothing$ ses i 1517-årsalderen. Dels har vel oppløsningstidspunktet sammenheng med at behovet for gjengsamvær er mindre når man kommer opp i den alderen. Vi skal snart komme nærmere tilbake 
også til dette. Dels har det vel også sammenheng med at tokjønnspreget f $\varnothing$ rer til gruppens oppl $\varnothing$ sning. Det skapes etterhvert stabile par-forbindelser $i$ en norsk ungdomsgruppe, eller det skapes konkurransesituasjoner og sjalusi som sprenger systemet. Ofte vil det vel også være slik at ungdomsgruppen oppløses fordi medlemmene blir interessert i personer av det annet kjønn utenfor systemet. Den sicilianske gjengen går ikke på langt nær så hurtig i oppløsning. Det normale mønster dér er at den fortsetter inntil ekteskap. De sicilianske deltakerne har på dette området helt motsatte behov av dem som manifesterer seg i den norske gruppe. I Norge vil forholdet mellom to personer av motsatt kjønn f $\varnothing \mathrm{re}$ til at man forlater ungdomsgruppen, om ikke annet så for å være alene med sin elskede. I et siciliansk milj $\phi$ med uendelig mer strikse regler om f $\phi$ rekteskapelige forbindelser vil ungdomsgruppen yte en helt uerstattelig service for de to unge. Det er utenkelig å la de to ferdes på egen hånd. Det er bare sammen med de mange at de kan være alene.

Men ved disse forskjeller er ytterligere forskjell skapt: Aldersforskjellen i den sicilianske ungdomsgruppen, slektningenes tilstedeværelse, kommunikasjonen over til foreldre - det bidrar alt sammen til å få tilværelsen i ungdomsgruppen til å ligne nokså meget på tilværelsen som man senere skal inn i. Ungdomsgruppen blir et samfunn i miniatyr med verdier og regler i samsvar med de voksnes verden. Overgangen fra gjengmedlem til voksen blir preget av kontinuitet. Den norske spontant fremvokste ungdomsgruppen blir også her av en helt annen natur. Gruppeaktiviteten blir langt mindre kontrollert av foreldre og andre foresatte, men omvendt har også de unge reduserte påvirkningsmuligheter. Det oppstår meget lettere en generasjonskl $\phi$ ft. Den norske ungdomsgjeng blir like meget en reaksjon mot familien, som den sicilianske en slags tidlig kopi. Likevel, kanskje de begge har felles at de gjør en senere tilpasning mulig.

For å belyse dette problemet må vi ta en avstikker til familiens situasjon $\mathrm{i}$ de to samfunn.

\section{III.}

På ny finner vi avgjørende forskjeller. Den norske familie må i h $\phi y$ grad kunne sies å være preget av industrisamfunnets krav. Den norske familie har tilpasset seg disse krav i ekstrem grad. Den er nå blitt omformet slik at både vertikal og horisontal mobilitet er blitt mulig. Konkurransesamfunnet fører til en rekke vertikale elevatorer som bringer forskjellige individer til forskjellige platåer. Noen fyker hurtig oppover i lagdelingssystemet, noen blir sittende på den plassen de er f $\varnothing \mathrm{dt}$, noen drar nedover. I denne situasjonen er det nokså komplisert å operere med en 
stor familieenhet. Som en f $\phi$ lge av bl. a. konkurransesamfunnets krav har vi fått den lille avskrellede familieenhet som vi nå er blitt så vant til at vi tar den som en selvfølge. Det er den lille kjernefamilien med mor, far og noen få barn, en enhet som er seg selv nok. En stфrre enhet ville være upraktisk for å si det mildt. Hvor ett medlem avanserte oppover og ett annet nedover på den sosiale rangstige, ville det oppstå helt umulige situasjoner. I tillegg kommer behovet for horisontal eller geografisk mobilitet. Dommerfullmektigtiden tilbringes i Harstad, departementssekretæren kommer til Oslo, deretter blir det en periode i Mo i Rana, deretter en periode på Hamar. En storfamilie hvor flere personer har yrker som krever at de reiser til forskjellige deler av landet ville på ny skape helt umulige situasjoner. Den avskrellede familien er fortsatt best egnet til å løse også dette problemet.

Den sicilianske familien har i langt mindre grad gitt etter for disse krav fra industrisamfunnet. Denne familien er mer stedbunden, klasseskillene er også mer rigide. Man forblir der man er f $\varnothing \mathrm{dt}$. Begge deler gj $\phi \mathbf{r}$ det mulig å ha en stor familie. Ja, ikke bare mulig, men ofte til og med nødvendig for å holde på privilegiene og for å hjelpe hverandre.

Men med disse to familietyper, den lille tett sammenknyttede kjernefamilien og den adskillig st $\varnothing$ rre sicilianske familien, vil det også oppstå helt forskjellige behov. I et norsk industrisamfunn er barna ofte objektivt sett en byrde og belastning - de skal ikke ta vare på noen slektsgård, de vil ikke annet enn indirekte komme til å fors $\phi$ rge sine foreldre. Betalingen for foreldrenes ydelser skjer mer i form av symboler på kjærlighet og hengivenhet. Samtidig er barna forferdelig avhengig av foreldrene. Det står som oftest ikke andre slektninger klar til å overta den byrde hvis ul $\varnothing \mathrm{nn}$ er sikker. Barnet blir knyttet uendelig tett til foreldrene i denne familie, vekten på følelsene, på emosjonene, på kjærlighetens bånd blir helt avgjørende.

Men dette skaper problemer fordi båndene på ny en gang må løsnes. Det begynner allerede meget tidlig. I småfamilien vil moren være den dominerende hjemmeværende modell for barnas livsf $\phi$ rsel. Både pikene og guttene identifiserer seg med henne, men guttene blir litt etter litt gjort oppmerksomme på at dette er en stor misforståelse. Gutten skal ikke bli mor og må se seg om etter andre modeller, men her er det jo til å begynne med slett ingen hjemme. Faren forsvinner uavlatelig ut av systemet. Hans yrkesrolle blir ikke spilt ut inne i familien. Faren er bare hjemme i fritiden. Gutten får en mannlig fritidsmodell. Det ligger en fascinerende tråd fra dette fenomenet og over i Matza og Sykes (1961) påstand om at lovovertredere på en måte prøver å realisere middelklassesamfunnets fritidsidealer. Den moderne 
lovovertreder er en karikatur av forrige århundres velstående rentenist. Dessuten: I mangel av en hjemmeværende far vil gutten lett utvikle en tvangsmessig maskulinitet. Tillers (1958) unders $\varnothing$ kelse av sjømannss $\varnothing$ nnenes problem er her meget relevant. Men det er ikke bare moren som gutten må frigjøre seg fra. Vissheten henger der hele tiden: F $\phi \mathbf{r}$ eller senere skal familiesystemet splittes i to. Foreldre og barn skal helt skille lag. Det er jo nettopp hovedprinsippet i systemet at kjernefamilien på ny og på ny skal gå i oppløsning.

Her kommer kontrasten til den sicilianske familien for alvor inn i bildet. Denne familien har ikke på samme måte tilpasset seg det moderne industrisamfunns krav. S $\varnothing r-I t a l i a$ representerer i langt høyere grad et stedbundet klassesamfunn som gj $\phi \mathbf{r}$ det mulig å etablere en meget større familieenhet med kontinuitet både bakover og forover. Ungdomsgruppen dér vil i tilsvarende grad ta vare på helt andre behov enn den norske ungdomsgruppen. Det blir en hyggelig samværsform for ugifte. Det blir en møteplass for ungdom - et sted gutter og piker kan være sammen og tillates å være sammen. Den norske gjengen vil derimot i langt større grad ta vare på behovet for frigjøring. Småbarnsalderens familieliv er trening i emosjonelle tilknytninger. Så følger en periode hvor det oppstår ufravikelige krav om at disse sterke båndene skal kuttes over. I denne situasjonen må nettopp ungdomsgjengen representere en verdifull overgangsordning. Anhengigheten kan i en mellomfase overf $\varnothing$ res til andre. Vennene tar foreldrenes plass. Men det som skjer i disse gruppene, og de regler som der utformes, vil lett komme til å stå i konflikt med de voksnes regler. Fordi foreldretilknytningen har vært så sterk, men likevel må oppløses, blir ungdomskulturens innhold ofte det motsatte av foreldrekulturens. Ungdomskulturen tar derved vare på reaksjonsbehov.

Gjengen er uunngåelig og kanskje nyttig. Men den kan også bli farlig, sett fra en kriminalpolitisk synsvinkel. Opproret kan ta overhånd. Fenomenet med den normative misforståelse — at alle tror at alle andre egentlig фnsker å gå lengre - kan her spille en viktig rolle, jfr. Hauge (1963). På forhånd avvikende personlighetstyper kan også komme til å dominere. Potensielle lovbrytere har mange fordeler ved — i dobbelt betydning — å henge sammen i en gjeng. De får praktisk hjelp, og de oppmuntres i sit avvik. De fleste lovbrytere vil være ambivalente overfor sin gjerning. Gjengen hjelper til med å overvinne tvilen, og gjør det på en måte mulig å realisere begge sider av dilemmaet. Samfunnets regler brytes - gjengens regler blir hellige. 
IV.

Meget relevant for kriminologiske formål er imidlertid sp $\phi$ rsmålet om det er mulig å skille mellom de kriminelle og de ikke kriminelle gjengene på basis av ytre kjennetegn. Er de bygget opp på helt samme måte, eller foreligger det visse systematiske forskjeller i deres struktur? Spesielt ville det være nyttig om man kunne slå ned på lett synlige kjennetegn. Man ville få et middel til diagnose, og til forebyggende tiltak.

Denne type strukturanalyse av kriminelle kontra ikke-kriminelle gjenger er forel $\varnothing$ pig en kriminologisk mangelvare. Det f $\varnothing 1$ gende fors $\phi \mathrm{k}$ er derfor bare ment som en upretensi $\phi$ s idé-skisse som forhåpentligvis en gang kan bli etterprøvet.

La oss på ny sette opp en stikkordliste. Denne gang holder vi oss innen Norge. Kontrastene blir mellom kriminalitetstruede kontra ,vanlige" ungdomsgrupperinger, og mange av våre gamle variabler dukker opp på ny.

\section{Norske gjenger}

\section{Ikke kriminalitetstruede}

Aldershomogene

Stedshomogene

Kjønnsheterogene

Verbalkontakt.

Middels varige

\author{
Kriminalitetstruede \\ Aldersheterogene \\ Stedsheterogene \\ Kjønnshomogene (eller eksepsjo- \\ nelt lav rang til kvinnene) \\ Symbolkontakt \\ Ekstremt varige eller ekstremt \\ kortvarige
}

Viktigst i listen er kanskje at de norske kriminalitetstruede gjengene ser ut til å være mer både alders- og stedsheterogene enn det som er vanlig. De ligner forsåvidt på de sicilianske grupperingene. Om dette er riktig, kan det som Brøgger (1963) er inne på, ha sammenheng med at deltakerne i de kriminalitetstruede gruppene har så spesielle behov for hverandre at de må saumfare store alders- og stedsområder f $\phi \mathbf{r}$ de finner noen å knytte seg til. De kan også ha vanskeligheter i sit nærmeste nabolag - vanskeligheter som får dem til å s $\phi$ ke litt fjernhet. Samtidig kan de ha behov for beundrere.

Hvordan nå dette enn kan være, så vil den eventuelle aldersog stedsheterogeniteten ha viktige sosiale konsekvenser. Aldersheterogeniteten vil forst og fremst gi muligheter for å samle og bevare en tradisjon i gruppen. I et slikt system vil nye medlemmer som oftest komme til fra bunden, gamle skrelles av fra toppen. På denne måten vil det alltid være noen til stede som husker de gamle og lærer opp de unge. Den spesielle gjengkulturen kan bevares $\mathrm{i}$ årevis. Dette $\mathrm{i}$ skarp kontrast til forholdene 
i de vanlige aldershomogene grupperingene. Et spesielt segment vil her komme sammen som 12-13-åringer, og så i langt større grad eldes sammen inntil de går fra hverandre som 17-18. Det de har sanket av erfaring og tradisjon vil d $\varnothing$ med gjengen. Det er ingen til å bringe det videre. Hvert nytt kull må finne på det hele fra bunden av. Forskjellen må for $\phi$ vrig ikke overvurderes. Aldershomogeniteten vil sjelden være absolutt. Og de aldersheterogene gruppene vil ofte gå i fullstendig oppløsning og miste sin tradisjon som følge av medlemmenes mer ustabile karakter.

Om aldersheterogeniteten virker tradisjonsskapende, så vil stedsheterogeniteten føre til at nabolaget får mindre sjanse til å kontrollere disse grupperingene. De flakker, de undrar seg enda mer enn vanlig foreldres og naboers voktende $\phi y n e$. Men til gjengjeld utsetter de seg i større grad enn normalt for det offisielle samfunns kontroll. Her står vi trolig overfor et spesielt skandinavisk fenomen. Den sosiale utjevning som har funnet sted, spesielt avskaffelsen av de typiske slum-distriktene, skaper vanskeligheter for avvikerne når det gjelder å bestemme seg for m $\phi$ teplasser. Det finnes ikke lenger så naturlige møteplasser på samfunnets skyggeside, og de vil derfor s $\varnothing$ ke mot str $\varnothing \mathrm{k}$ de har felles på lyssiden. De vil møtes i Centrum - i Studenterlunden eller Kungsgatan, i $\operatorname{str} \phi \mathbf{k}$ hvor de ved kontrastvirkning blir meget synlige. At de svenske blir enda mere synlige enn de norske, har vel trolig sammenheng med at nivået der er hфyest, og dessuten at den norske handelsflåten absorberer en langt st $\phi$ rre andel avvikere som ellers ville vært synlig på drift. Avvikene blir vel for $\emptyset$ vrig også mere synlige i Skandinavien enn i mange andre land fordi det hos oss ikke bare er boligmessig homogenitet, men også idémessig. Den skandinaviske ungdomskulturen er i høyden todimensjonal, mens f.eks. den amerikanske er mangedimensjonal. Det er hos oss enighet om så mange ting at det blir et klarere og mer iøynefallende skille mellom riktig og galt. Man må også av den grunn vente at ungdomskulturen blir mer splittet $\mathrm{i}$ godt og ondt hos oss, mens de mange aksepterte løsninger i mange land gir flere muligheter for respektable avvik. Man får utl $\phi p$ for avvikstendenser ved å hate negre, demokrater, sosialister eller kapitalister, og integreres derved i samfunnet på en mer akseptabel måte (Cfr. Karacki og Toby 1962).

Tilbake til stikkordlisten: Kjønnshomogeniteten er et trekk som gjør at de kriminalitetstruede grupperingene skiller seg både fra vanlige ikke kriminalitetstruede norske grupperinger og fra den sicilianske gjengen vi har beskrevet. Heller ikke her dreier det seg om et absolutt enten eller. Noen kriminalitetstruede gjenger vil trolig ha en del piker som medlemmer. I slike tilfelle tyder imidlertid mye på at pikene vil ha eksepsjonelt lav rang i systemet - eller - og det vil ofte ha sammenheng med rangen 
- de vil være meget yngre enn guttene. I noen tilfelle later det til at noen svært guttaktige jenter er med i gjengen. Det er slike som blir akseptert ved på en måte å være mer gutt enn gutta, ved å overoppfylle alle forventninger. Hovedtendensen later imidtid til å gå i retning av kjønnshomogenitet ved at de kriminalitetstruede grupperinger er utpreget guttegjenger. Stort sett vil antakelig dette forhold f $\varnothing$ re til at disse grupperingene stabiliseres. Det blir ikke så mange erotisk emosjonelle konflikter innen gjengene. Det blir ikke forstyrrende indre konkurranseforhold. En annen konsekvens av det manglende pikeinnslaget vil trolig være at disse gjengene blir overdrevet maskuline. De har ikke kvinner med som kan dempe dem. De har heller ikke kvinner med som de kan måle sin mannhaftighet mot, de må være mer mandige enn andre menn. Denne tendensen blir sikkert ytterligere styrket ved at mange av gjengmedlemmene på forhånd er usikre $\mathrm{i}$ sitt forhold til kvinner, og derved til seg selv som menn. De ekstreme, i sine ytringsformer ofte nokså st $\varnothing$ tende, former for seksualliv i raggarbilene har kanskje sammenheng med dette.

De kriminalitetstruede gjengene rekrutteres fra st $\varnothing$ rre geografisk- og aldersmessig område. Når de likevel klarer å finne hverandre, skyldes det trolig f $\varnothing$ rst og fremst at de symboliserer sine avvikertendenser på forskjellige måter. Ved klær, frisyre og ytre atferd gjør de klart at her er personer som har ganske bestemte tendenser og problemer. De ytre kjennetegn som støter andre og fortviler foreldre tjener m. a. o. vigtige funksjoner som kontaktformidlere. Dobbelt viktige blir disse symbolene fordi denne gruppe ungdom later til å være mindre orientert om verbal kommunikasjon. De er mindre dyktige til å snakke med tungen enn med resten av kroppen og med klær og skjegg. Bernstein (1960) har antydet at bestemte typer oppdragelse kan f $\varnothing$ re til manglende verbal evne, og Brøgger (1963) har påvist hvordan dette fenomenet er utpreget for en ungdomsgjeng han har studert i et storbymilj $\phi$. Men det er klart at også dette trekk har en slags selvoppholdende karakter. De samme symboler som den kriminalitetstruede ungdom benytter for å finne hverandre, benyttes av andre til å forkaste dem og til å gjøre dem enda mere avhengige av personer i samme båt.

Det siste ledd i listen gikk ut på at de ikke kriminalitetstruede grupperingene var av en slags middels varighet, mens de kriminalitetstruede var å finne på begge ekstremer, enten som spesielt varige system eller som spesielt kortvarige. Hvis dette er riktig, er forklaringen antagelig at gjengmedlemmene i de kriminalitetstruede grupperingene betyr mer for hverandre. De manglende kvinner, de manglende alternativer, sammen med gjengtradisjonen som kan skapes ved de aldersheterogene grup- 
peringene, det kan alt sammen komme til å styrke grupperingene. På den annen side må man regne med at de enkelte medlemmer er langt mer ustabile som personlighetstyper. Sterke behov holder sammen personer som egentlig er lite kompetente til samvær. Brøgger (1963) sier det slik: „Hvis en ungdomsgruppe i særlig grad understreker vennskap og samhold, kan det paradoksalt nok være at manglende evne til vennskap er et felles trekk for dens medlemmer".

Det må enda en gang gjøres klart at dette fors $\varnothing$ ket på å beskrive noen strukturelle forskjeller mellom kriminalitetstruede og ikke særlig kriminalitetstruede ungdomsgrupperinger bare er et fors $\phi k$. Det er bygget på spredt iakttagelse, det har bare som formål å fors $\phi$ ke å hugge ut noen knagger som vi kan plassere fenomenene på for å få dem ordnet på en eller annen måte. La det også være tilf $\phi y e t$ at kriminalitetstrusselen kanskje ikke er den - sett fra samfunnets synsvinkel - farligste manifestasjon av atferdstendensene. Det som hos oss fører til brysom småkriminalitet, kunne i en annen ramme føre til politisk kriminalitet. Nasjonalsosialistiske ungdomsgrupper hadde utvilsomt mange trekk til felles med våre kriminalitetstruede ungdomsgrupperinger. Fra samfunnets synsvinkel kan det ikke være særlig tvilsomt hvilken manifestasjon som er lettest både å ford $\varnothing$ ye og å bekjempe.

\section{LITTERATUR.}

Bernstein, Basil: Language and Social class. Br. J. Sociol, 1960, XI, $271-276$.

Brøgger, Jan: Om gjengstruktur hos storbyungdom. Oslo 1963, 60 s. Stensil. Institutt for kriminologi og strafferet.

Hauge, Ragnar: Gjengkriminalitet. Nordisk Tidsskrift for Kriminalvidenskab, 1963, 51, 74-89.

Karacki, Larry \& Jackson, Toby: The uncommitted adolescent. Candidate for gang socialization. Sociological Inquiry, 1962, 32, $203-215$.

Matza, David \& Gresham Sykes: Juvenile delinquency and subterranean values. Am. Sociological Revue, 1961, 26, 712-719.

Tiller, Per Olav: Father absence and personality development of children in sailor families. Nordisk Psykologisk monografserie $\mathrm{nr}$. 9, 1958, 48 sider. 